\title{
Development of religious tourism and history of Complex Syekh Burhanuddin tomes in Nagari Ulakan, District Padang Pariaman
}

\author{
Hayati Otari $^{1}$, Siti Fatimah ${ }^{2}$ \\ ${ }^{1}$ Social Education Program, Postgraduate Faculty, Universitas Negeri Padang \\ ${ }^{2}$ Universitas Negeri Padang
}

\begin{abstract}
This research begins with the observations and observations of the author when visiting Syekh Burhanuddin Nagari Ulakan's Religious Cemetery of Ulakan Tapakis Subdistrict, Padang Pariaman Regency, that unknown attractions, narrow accessibility, inadequate tourist facilities and tourist activities in tourist attractions Religious Tomb of Sheikh Burhanuddin. This study aims to analyze how the Development of Religious Tourism and the History of Syekh Burhanuddin's Tomb in Padang Pariaman Regency is seen from four indicators of development potential, namely attractions, accessibility, amenities, and activities. This type of research is a qualitative method research using SWOT analysis. The technique of data collection is done using the method of interview, observation, documentation, and SWOT analysis. The technique of data collection was done by interviewing the tomb guards and those who knew more about Sheikh Burhanuddin's grave, and using the SWOT analysis. Religious activity in the area has brought vast impact on the surrounding region, either in the form of the development of economic activities, the development of settlements and the like, however the development of the area has not been coupled with completeness basic facilities and infrastructure are adequate in supporting religious activities as well as a growing tourism activities.
\end{abstract}

Keywords: development, religious tourism object, the tomb of Shekh Burhanuddin

\section{PENDAHULUAN}

Sumatera Barat termasuk salah satu wisata religi yang disiapkan di Indonesia karena memiliki berbagai obyek wisata yang terdapat di beberapa Kota dan Kabupaten yang ada di Sumatera Barat sebagai tujuan dari wisatawan untuk berkunjung dalam kegiatan ziarah. Salah satu obyek wisata religi yang di kunjungi oleh wisatawan di Sumatera Barat yaitu terdapat di Kabupaten Padang Pariaman Salah satu wisata religi yang ada di Kabupaten Padang Pariaman terdapat di Ulakan Kabupaten Padang Pariaman yaitu Objek Wisata religi Makam Syekh Burhanuddin.Syekh Burhanuddin adalah orang yang menyebarkan agama Islam di Sumatera Barat dan sekitarnya sehingga banyak pengikutnya.Ulakan merupakan salah satu daerah yang memiliki nilai sejarah salah satunya terhadap pengembagan ajaran agama Islam di wilayah Sumatra Barat dan sekitarnya.Ulama tersebut adalah Syekh Burhanuddin yang sangat dikenal oleh penduduk lokal maupun penduduk mancanegara. Disinilah tempat di semayamkanya Syekh Burhanuddin dimana tempat ini di jaga dan dilestarikan baik oleh masyarakat maupun pemerintah, tempat ini memiliki potensi dan daya tarik wisata yang khas, yaitu kompleks makam Syekh Burhanudin dan pantai Ulakan yang berada di Kecamatan Ulakan Tapakis Kabupaten Padang Pariaman.

Kawasan wisata religious makam syekh burhanuddin ini merupakan kawasan yang sangat potensial untuk dikembangkan karena kawasan selalu ramai dikunjungi terutama di bulan Syafar atau dikenal dengan bersyafar oleh masyarakat sekitar berupa kunjungan ziarah ke kawasan makam Syekh Burhanuddin sebagai Ulama Besar 
Syatariah. Obyek wisata Religi Makam Syekh Burhanuddin mengalami peningkatan pengunjung pada acara Basafa, yaitu hari wafatnya Syech Burhanuddin yang diperingati pada 10 Sayafar.Acara tersebut terbagi dua yaitu safa ketek (hari meninggalnya syech) dan safa gadang (hari 7 hari meninggalnya syech), dua acara itu sangat ramai dikunjungi para peziarah setiap tahunnya. Syech Burhanuddin merupakan tokoh agama islam pada abad ke-17 yang dikenal di Minangkabau. Beliau dipercaya mempunyai kekuatan supranatural dan uga mempunyai pengetahuan yang mendalam mengenai agama islam, dan sampai sekarang makam beliau masih dikunjungi oleh peziarah. Karena Makam Syech Burhanuddin ini telah menjadi tempat wisata yang dibangun dengan bercirikan arsitektur masjid pada zaman abad ke-16.

Ada beberapa bekas-bekas dan hasil perjuangan beliau masih dapat disaksikan sampai sekarang, diantara peninggalan beliau dapat dijumpai, antara lain: 1) Komplek Makam, 2)Surau Tanjung Medan, 3) Al-qur'an Tua, 4) Pondokan Pesantren Syekh Burhanuddin, 5) Buku-buku Islam dan 6) Keris. Para peziarah akan melanjutkan perjalanan ke Surau Gadang di Tanjung Medan. Surau ini merupakan peninggalan Syekh Burhanuddin yang $100 \%$ terbuat dari kayu. Kesan "tua" pada surau tampak dari dinding dan tonggak utamanya yang telah berlubang dimakan rayap. Surau yang mampu menampung ratusan jamaah tersebut hingga kini masih digunakan oleh masyarakat Tanjung Medan. Biasanya, surau tersebut digunakan untuk salat pada bulan Ramadan. Di depan surau, peziarah akan melihat Pondok Pesantren Luhur Syekh Burhanuddin. Acara Basafar di Komplek makam Syekh Burhanuddin dilakukan tiap tahun pada tanggal 10 bulan Safar.

\section{METODE PENELITIAN}

Jenis penelitian yang dilakukan dalam penelitian ini adalah jenis penelitian dengan metode kualitatif dengan menggunakan analisis SWOT (Sugiyono (2011: 334). Sumber data penelitian ini yaitu melalui informan dari Kepala Seksi Usaha Pariwisata Dinas Pemuda, Kebudayaan, dan pariwisata Kabupaten Padang Pariaman, Pengelola Makam Syech Burhanuddin, dan wisatawan yang berkunjung ke Objek Wisata Religi Makam Syekh Burhanuddin. Pemilihan informan sebagai sumber data penelitian menggunakan analisis SWOT. Teknik pengumpulan data dilakukan dengan cara observasi, wawancara, dokumentasi, dan analisis SWOT.

\section{HASIL}

Tabel 1. Upaya dalam pengembangan objek wisata religi dan sejarah di Nagari Ulakan Kecamatan Ulakan Tapakis Kabupaten Padang Pariaman melalui analisis SWOT

\begin{tabular}{|c|c|c|}
\hline Kekuatan (S) & Kelemahan (W) & Strategi S-W \\
\hline $\begin{array}{l}\text { 1. Lokasi komplek makam yang } \\
\text { strategis dan dekat dengan } \\
\text { pantai } \\
\text { 2. Akses jalan menuju objek } \\
\text { wisata sangat baik } \\
\text { 3. Pelayanan yang ramah tamah } \\
\text { dan memuaskan } \\
\text { 4. Keamanan dan kenyamanan } \\
\text { yang baik } \\
\text { 5. Sarana dan prasarana sudah } \\
\text { cukup memadai }\end{array}$ & $\begin{array}{l}\text { 1. } \begin{array}{l}\text { Kurangnya perhatian } \\
\text { pemerintah untuk lebih }\end{array} \\
\text { mengembangkan sarana dan } \\
\text { prasarana objek wisata } \\
\text { 2. Kurang terawatnya mushalla } \\
\text { peninggalan dari Syekh } \\
\text { Burhanuddin } \\
\text { 3. Tidak adanya Transportasi } \\
\text { khusus } \\
\text { 4. Kebersihan yang masih } \\
\text { kurang dijaga } \\
\text { 5. Ketertiban untuk parker } \\
\text { motor yang kurang memadai }\end{array}$ & $\begin{array}{l}\text { 1. Memperbaiki dan melengkapi } \\
\text { fasilitas yang belum tersedia } \\
\text { seperti tikar atau sajadah tempat } \\
\text { beribadah } \\
\text { 2. Lebih memperpahtikan kebersihan } \\
\text { disekitar komplek makam Syekh } \\
\text { Burhanuddin } \\
\text { 3. Menghidupkan jalur angkutan } \\
\text { umum supaya wisatawan bisa } \\
\text { langsung menuju ke objek wisata } \\
\text { tersebut } \\
\text { 4enyediakan tempat parkir untuk } \\
\text { kendaraan bagi para pengunjung }\end{array}$ \\
\hline Peluang (O) & Ancaman (T) & Strategi O-T \\
\hline $\begin{array}{l}\text { 1. Adanya kerjasama antara } \\
\text { pemerintah dengan pengelola } \\
\text { untuk lebih mengembangkan } \\
\text { objek wisata religi makam } \\
\text { Syekh Burhanuddin }\end{array}$ & $\begin{array}{l}\text { 1. Timbulnya rasa kecewa para } \\
\text { penziarah karena tempat } \\
\text { parkir yang tidak memadai }\end{array}$ & $\begin{array}{l}\text { 1. Meningkatkan kerja sama antara } \\
\text { pemerintah daerah dengan } \\
\text { pengelola objek wisata religi } \\
\text { komplek makam Syekh } \\
\text { Burhanuddin }\end{array}$ \\
\hline $\begin{array}{l}\text { 2. Adanya rencana pemerintah } \\
\text { untuk lebih memperbaiki dari } \\
\text { mushalla-mushalla untuk }\end{array}$ & $\begin{array}{l}\text { 2. Kurangnya fasilitas yang } \\
\text { disediakan ketika acara } \\
\text { basafar. }\end{array}$ & $\begin{array}{l}\text { 2. Meningkatkan promosi dan } \\
\text { website peta lokasi untuk menarik } \\
\text { wisatawan }\end{array}$ \\
\hline
\end{tabular}


penginapan para penziarah

3. Adanya penunjuk arah dibuat oleh pengelola dijalan menuju daerah objek wisata religi tersebut

4. Aktifitas berziarah pada makam Syekh Burhanuddin
3. Meningkatkan fasilitas sarana dan prasarana dan pelayanan terhadap wisatawan yang datang berkunjung

\section{PEMBAHASAN}

Dari tabel analisis SWOT di atas, dapat dilihat bahwa strategi yang dapat dilakukan untuk pengembangan Objek Wisata Religi dan Sejarah Komplek Makam Syekh Burhanuddin Nagari Ulakan adalah :

Pertama, Memperbaiki dan melengkapi fasilitas yang belum tersedia seperti tikar atau sajadah di tempat pemakaman. Dengan memperbaiki sarana dan prasarana yang telah ada akan membuat pengunjung semakin betah bahkan membuat pengunjung berkeinginan untuk datang kembali. Kedua, Memperhatikan kebersihan dan perawatan lokasi objek wisata religi supaya keliatan bersih dan rapi. Kebersihan sangat mempengaruhi minat pengunjung, tempat yang bersih membuat pengunjung merasa nyaman dan betah berlama-lama bahkan ingin kembali lagi.

Ketiga, Menghidupkan jalur angkutan umum supaya wisatawan bisa langsung menuju ke objek wisata tersebut. Transportasi merupakan hal yang penting untuk objek wisata. Dengan adanya transporasi khusus menuju objek wisata religi makam Syekh Burhanuddin akan memudahkan pengunjung untuk datang. Keempat, Membuat atraksi wisat yang merupakan cirri khusus dari objek wisata. Atraksi wisata merupakan suatu penarik dalam dunia pariwisata, dengan adanya atraksi wisata yang bisa dinikmati pengunjung, apalagi jika yang ada di objek wisata religi makam Syekh Burhanuddin.

Kelima, Meningkatkan kerja sama antara pemerintah daerah dengan pengelola objek wisata religi makam Syekh Burhanuddin. Adanya kerjasama pemerintah, pengelola dan masyarakat akan lebih mempermudah dalam pengembangan objek wisata religi makam Syekh Burhanuddin. Keenam, Meningkatkan promosi dan website peta lokasi menarik wisatawan. Dengan adanya website peta lokasi akan memudahkan pengunjung untuk menuju objek wisata religi makam Syekh Burhanuddin, karena peta lokasi merupakan petunjuk yang mudah dimengerti dari pada Cuma sekedar bertanya dari satu orang ke orang lainnya.

\section{KESIMPULAN}

Kekuatan dari objek wisata religi dan sejarah komplek makam Syekh Burhanuddin adalah pertama, Lokasi komplek makam yang strategis dan dekat dengan pantai. Kedua, Akses jalan menuju objek wisata sangat baik. Ketiga, Pelayanan yang ramah tamah dan memuaskan. Keempat, Keamanan dan kenyamanan yang baik. Kelima Sarana dan prasarana sudah cukup memadai. Kelemahan dari objek wisata religi dan sejarah komplek makam Syekh Burhanuddin. Pertama, Kurangnya perhatian pemerintah untuk lebih mengembangkan sarana dan prasarana objek wisata. Kedua, Kurang terawatnya mushalla peninggalan dari Syekh Burhanuddin. Ketiga, Tidak adanya Transportasi khusus. Keempat,Kebersihan yang masih kurang dijaga. Kelima, Ketertiban untuk parker motor yang kurang memadai.

\section{DAFTAR RUJUKAN}

Bustamam. (2000). Syekh Burhanuddin Ulakan. CV. Indo Jati.

Damardjati R.S. (1989). Istilah-istilah Dunia Pariwisata. Jakarta: Pradnya Paramita.

Gottschalk, Louis. (1975). Mengerti Sejarah. Jakarta: UI Press

Ida Bagus Suryawarman. (2014). "Pengembangan Pelabuhan Cruise Tanah Ampo Sebagai Gerbang Pariwisata Kabupaten Kerangasem”. Jurnal Pariwisata, 2 (2)

Inu Kencana Syafiie. (2009). Pengantar Ilmu Pariwisata, Bandung: Mandar maju.

Irfan Dzikriazak. (2018). "Dampak Kegiatan Pariwisata Olahraga Internasional Tour de Linggarjati Terhadap Kepariwisataan Kabupaten Kuningan”. Jurnal Pariwisata, 1 (2)

Mahkota, Ambas. (2000). Sejarah Syekh Burhanuddin Ulakan. Padang: CV. Indo Jati

Niluh Herawati.(2015). "Pengembangan Pariwisata Berkelanjutan Berbasis Subak Sebagai Bagian Warisan Budaya Dunia UNESCO di Desa Mangesta Kabupaten Tabanan”. Jurnal Pariwisata, 2 (1) 
Nono Wibisono. (2018). “Analisa Persepsi Wisatawan Terhadap Jawa Barat Sebagai Destinasi Wisata”. Jurnal Pariwisata, 8 (1)

Nuruddiin. (2018). "Strategi Pengembangan Situs Bersejarah Sebagai Bisnis Pariwisata Warisan Budaya". Jurnal Sejarah, 8 (1)

Nyoman S. Pendit, Ilmu Pariwisata Sebuah Pengantar Perdana.

Moleong, Lexy J. (2012). Metode Penelitian Kualitatif. Bandung: Remaja Rosdakarya

Purwadi. (2006). Jejak Para Wali dan Ziarah Spritual. Jakarta: Kompas.

Seriany Tonglo. (2016). "Upaya Pembedayaan Masyarakat Lokal pada Daya Tarik Wisata Lemo,Kecamatan Makale Utara,Kab Tanah Toraja”. Jurnal Pariwisata, 4 (1)

Sugiyono. (2010). Metode Penelitian Kuantitatif Kuantitatif Dan R\&D. Bandung: Alfabeta

Sumandi, Suryabrata. (2008). Metodologi Penelitian. Jakarta: PT Raja Grafindo Persada

Tim Penyusun Kamus Pusat Bahasa. (2002).Kamus Besar Bahasa Indonesia, Jakarta: Balai Pustaka

Umar, Husein.(2003). Metode Penelitian untuk Skripsi dan Tesis Bisnis. Jakarta: PT Raya Grafindo Persada Yoeti, O. (1996).Pengantar Ilmu Pariwisata. Bandung. Angkasa.

Zed, Mestika. (1999). Metodologi Sejarah. Padang: Jurusan FIS UNP 